\title{
Lead determination in canned food by square-wave adsorptive cathodic stripping voltammetry
}

\author{
Puchong Wararattananurak, Pipat Chooto, Panit Sherdshoopongse, Chatjira Chuaynukool, \\ Chalermpol Innuphat* \\ Department of Chemistry, Analytical Chemistry Division, Faculty of Science, Prince of Songkla University, \\ Hatyai, Songkhla 90112 Thailand
}

*Corresponding author, e-mail: chalermpoli@ hotmail.com

Received 16 Aug 2014

Accepted 31 Oct 2014

\begin{abstract}
A sensitive and rapid method to analyse $\mathrm{Pb}(\mathrm{II})$ in canned fish samples was developed using square-wave adsorptive cathodic stripping voltammetry based on the adsorptive accumulation of 8-hydroxyquinoline complexes of $\mathrm{Pb}$ (II) onto a hanging mercury drop electrode, followed by reduction of adsorbed species by voltammetric scan with square wave pulse modulation. The optimum conditions were found to be $0.1 \mathrm{M} \mathrm{CH}_{3} \mathrm{COONH}_{4}$ as a supporting electrolyte, $\mathrm{pH} 7.5$, 8-hydroxyquinoline concentration of $15 \mu \mathrm{M}$, accumulation potential $-0.70 \mathrm{~V}$ (versus $\mathrm{Ag} / \mathrm{AgCl}$ ), accumulation time $120 \mathrm{~s}$, scan rate $0.3 \mathrm{~V} / \mathrm{s}$, and pulse amplitude $20 \mathrm{mV}$. Under the optimum conditions a linear calibration graph was obtained in the concentration range of $0.5-90.0 \mu \mathrm{g} / \mathrm{l}$ with correlation coefficient 0.9973 , a limit of detection of $0.108 \mu \mathrm{g} / \mathrm{l}$, and a limit of quantification of $0.360 \mu \mathrm{g} / \mathrm{l}$. The recovery values were obtained in the range $93.7-95.1 \%$. The relative standard deviations $(n=10)$ at lead concentration $5.0 \mu \mathrm{g} / \mathrm{l}$ was $2 \%$. The method was successfully applied to the determination of lead content in canned fish samples. The concentration of $\mathrm{Pb}$ (II) in canned fish samples (wet weight) was found to be in the range of $0.121-0.285 \mu \mathrm{g} / \mathrm{g}$, which is lower than the limit $(1.00 \mu \mathrm{g} / \mathrm{g})$ issued by the Ministry of Public Health of Thailand.
\end{abstract}

KEYWORDS: toxic elements, canned fish, electroanalytical techniques

\section{INTRODUCTION}

There is an increasing concern about the quality of food in several parts of the world in terms of contamination. Toxic elements in food have prompted studies on their toxicological effects and their determinations in food ${ }^{1}$ especially lead, which is able to contaminate food during harvesting, processing, and packaging ${ }^{2}$.

Fish is widely consumed in many parts of the world by humans because it has high protein content, low saturated fat, and high omega fatty acids known to promote good health. Canned fish in particular is extensively consumed in the developed world because it is convenient and affordable for most working families ${ }^{3}$. Their toxic metal content should be of some concern to human health. Fish may be contaminated by lead during fish growth, transportation, and storage. Contamination of lead may also occur during production handling and canning process ${ }^{3}$. Solder used in can manufacture is an important source of lead contamination in food during canning ${ }^{4}$. Lead is found at high concentration in muscles and organs of fish. It accumulates in the human body by replacing calcium in bones ${ }^{5}$.

Several methods have been investigated to determine lead at trace level including graphite fur- nace atomic absorption spectrometry ${ }^{6}$, atomic emission spectrometry (AES) especially when coupled with inductively coupled plasma (ICP-AES) ${ }^{7}$, inductively coupled plasma-mass spectrometry ${ }^{8}$, neutronactivation analysis ${ }^{9}$, and X-ray fluorescence spectrometry ${ }^{10}$. However, these techniques have the disadvantages of complicated operation, high cost of maintenance, expensive apparatus, and the requirement of well-controlled experimental conditions.

Electroanalytical techniques especially stripping analysis are well known as excellent procedures to determine trace chemical species with the advantages of low cost, high sensitivity, easy operation, and the ability of element speciation ${ }^{11}$. Stripping analysis is well recognized as one of the most suitable methods for trace metal determination. Its remarkable sensitivity is attributed to a combination of an effective preconcentration step with advanced measurement procedures that generate a high signal-to-background ratio since the metals are preconcentrated into the electrode by factors of $100-1000^{12}$. Adsorptive cathodic stripping voltammetry (AdCSV) is becoming increasingly popular to determine trace and ultratrace amounts of metal ions ${ }^{13}$. The technique is based upon adsorptive accumulation of the metal ion complex with a suitable ligand by adsorption at the surface of 
the electrode scanned in the negative direction ${ }^{14,15}$. The following reduction step, with a negative potential scan, can be used to measure the adsorbed complex. The adsorptive accumulation approach results in an effective preconcentration with short adsorption times (1-5 min) and highly sensitive and selective for trace metal measurements ${ }^{12}$.

The sensitivity in AdCSV is often greater than that in ASV due to the fact that the metal analytes do not dissolve in the mercury but form a complex layer on a mercury film electrode surface. Most AdCSV procedures utilize a hanging mercury drop electrode (HMDE) to measure reducible species, which offers the advantages of self-cleaning, reproducible surface area, and automatic control capability ${ }^{16}$. Because of the great sensitivity enhancement obtained with AdCSV methods, several complexing agents have been studied for the adsorptive collection of $\mathrm{Pb}$ (II) complexes on the HMDE including 8-hydroxyquinoline ${ }^{17}$, xylenol orange ${ }^{18}$, calcein blue ${ }^{19}$, morin $^{20}$, and thymolphthalexone ${ }^{21}$.

8-hydroxyquinoline (oxine) is a well known complexing agent for analytical determination of a number of cations of transition metals ${ }^{22}$. Since 8-hydroxyquinoline can be adsorbed on mercury, it is used in a preconcentration step for labile and non-labile complexes in electroanalytical procedures ${ }^{23}$.

An adsorptive cathodic stripping voltammetric technique was developed here to obtain optimized condition for trace measurement of lead based on effective accumulation of lead(II) complex with 8-hydroxyquinoline on a hanging mercury drop electrode.

\section{MATERIALS AND METHODS}

\section{Apparatus}

The voltammetric measurements were performed by Autolab PGSTAT100 combined with the GPES software, using a multi-mode electrode with the $\mathrm{HMDE}$ mode as working electrode, an $\mathrm{Ag} / \mathrm{AgCl} / 3 \mathrm{M} \mathrm{KCl}$ as a reference electrode and a $\mathrm{Pt}$ wire as an auxiliary electrode. Solutions were stirred during the purging and deposition steps by a rotating polytetrafluoroethylene rod. The electrode cell was equipped with a nitrogen purge tube to remove oxygen prior to sample analysis. Square wave voltammetry experiments were carried out with pulse amplitude $20 \mathrm{mV}$ and a scan rate of $0.3 \mathrm{~V} / \mathrm{s}$.

\section{Reagents and solutions}

All the reagents were of the analytical reagent grade and were used without further purifications. Deionized water was used throughout the investigation.
Glassware was rinsed with $10 \%(\mathrm{v} / \mathrm{v}) \mathrm{HNO}_{3}$ for $48 \mathrm{~h}$ followed by thoroughly rinsing with de-ionized water. Stock standard solution of $1000 \mu \mathrm{g} / \mathrm{l} \mathrm{Pb}(\mathrm{II})$ was prepared from $1000 \mathrm{mg} / \mathrm{l} \mathrm{Pb}(\mathrm{II})$ standard solution (SCP Science). Stock solution of 0.01 M 8-hydroxyquinoline (Fluka) was prepared by dissolving $1.11 \mathrm{~g}$ 8-hydroxyquinoline in $0.2 \mathrm{M} \mathrm{HCl}$ and then diluted with de-ionized water in a $50 \mathrm{ml}$ volumetric flask. The supporting electrolyte was $0.1 \mathrm{M}$ ammonium acetate which was adjusted to obtain $\mathrm{pH} 7.5$ by $0.1 \mathrm{M}$ ammonium hydroxide solution.

\section{Sample preparation and digestion}

Canned fish samples (mackerel in tomato sauce) of ten brands were purchased from local supermarkets. After opening the can, the fish and tomato sauce inside was homogenized thoroughly in a food blender. The homogenized sample (1.5 $\mathrm{g}$ wet weight) was placed into a beaker and $15 \mathrm{ml}$ of $\mathrm{HNO}_{3}$ : perchloric acid: $\mathrm{H}_{2} \mathrm{SO}_{4}$ mixture (25:25:1 v:v:v) was added. The beaker was covered by watch glass and heated on a hot plate at $150^{\circ} \mathrm{C}$ until the solution was clear. The clear solution was allowed to cool, transferred into a $25 \mathrm{ml}$ volumetric flask, and diluted to the mark with deionized distilled water ${ }^{5}$.

\section{General voltammetric procedure for sample solution}

The sample solution $(10 \mathrm{ml})$ containing $15 \mu \mathrm{M}$ 8-hydroxyquinoline and $0.1 \mathrm{M} \mathrm{CH}_{3} \mathrm{COONH}_{4}(\mathrm{pH}$ 7.5) was pipetted into a voltammetric cell. The stirrer was switched on and the solution was purged with nitrogen gas for $1 \mathrm{~min}$. After forming a new HMDE, accumulation proceeded for $120 \mathrm{~s}$ at $-0.7 \mathrm{~V}$ while stirring. At the end of the accumulation time, the stirrer was switched off and the solution was allowed to become quiescent for $10 \mathrm{~s}$. The voltammogram was then recorded by applying a negative potential differential pulse scan.

\section{RESULTS AND DISCUSSION \\ Adsorptive characteristics of the $\mathrm{Pb}$ (II)-8-hydroxyquinoline complex}

Preliminary experiments were performed to characterize the suitability of 8-hydroxyquinoline for the determination of lead ion using HMDE. Various stripping voltammograms are displayed in Fig. 1. All voltages are reported versus $\mathrm{Ag} / \mathrm{AgCl}$. Fig. 1a displays the voltammogram of $0.1 \mathrm{mM} 8$-hydroxyquinoline solution in $0.01 \mathrm{M}$ ammonium acetate at $\mathrm{pH} 8.0$ after 1 min accumulation at $-0.4 \mathrm{~V}$. Fig. $1 \mathrm{~b}$ shows the voltammogram of a solution containing $1 \mathrm{mg} / \mathrm{l}$ 
(a)

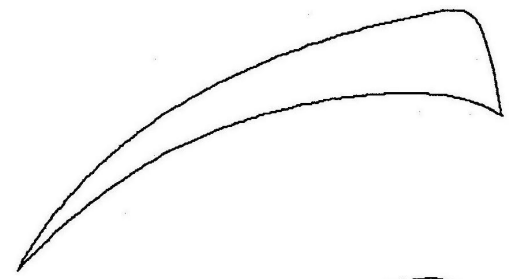

(b)
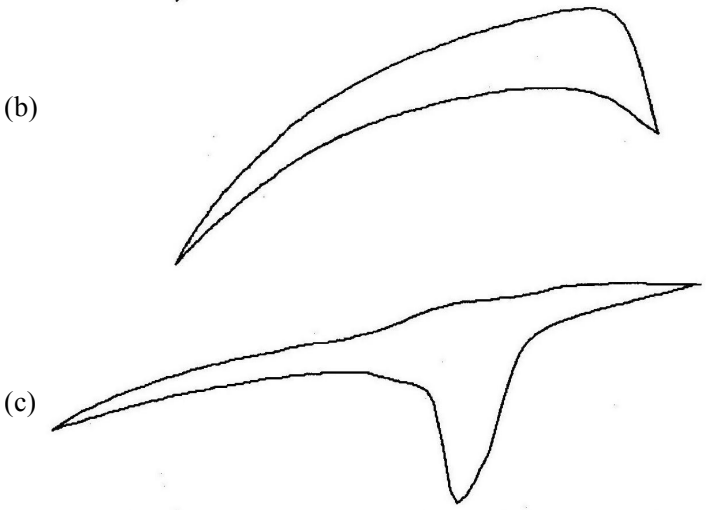

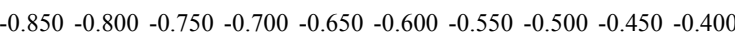

Potential (V) vs $\mathrm{Ag} / \mathrm{AgCl}$

Fig. 1 Stripping voltammogram of (a) $0.1 \mathrm{mM}$ 8-hydroxyquinoline, (b) $1 \mathrm{mg} / \mathrm{l} \mathrm{Pb}$ (II), and (c) mixture of $0.1 \mathrm{mM}$ 8-hydroxyquinoline and $1 \mathrm{mg} / \mathrm{l} \mathrm{Pb}$ (II) in $0.01 \mathrm{M}$ ammonium acetate at $\mathrm{pH} 8.0$ after $1 \mathrm{~min}$ accumulation at $-0.4 \mathrm{~V}$ and scan rate of $50 \mathrm{mV} / \mathrm{s}$.

$\mathrm{Pb}(\mathrm{II})$ in the absence of 8-hydroxyquinoline ligand under conditions similar to those in Fig. 1a. Fig. 1c shows the voltammogram of a mixture of $0.1 \mathrm{mM}$ 8-hydroxyquinoline and $1 \mathrm{mg} / \mathrm{l} \mathrm{Pb}(\mathrm{II})$ in $0.01 \mathrm{M}$ ammonium acetate at $\mathrm{pH} 8.0$ after $1 \mathrm{~min}$ accumulation at $-0.4 \mathrm{~V}$; a reduction peak at $-0.58 \mathrm{~V}$ was found. It can be concluded that the sensitivity of lead reduction currents is enhanced by the addition of 8-hydroxyquinoline to the solution, indicating that the $\mathrm{Pb}$ (II)-8-hydroxyquinoline complex was absorbed on the surface of electrode.

\section{The comparison between square wave and differential pulse}

A number of different waveforms have been used for the stripping step, including linear sweep voltammetry, differential pulse voltammetry (DPV), and square wave voltammetry (SWV). However, SWV and DPV are more commonly used due to their lower detection limits ${ }^{15}$. A comparison of the sensitivities for lead analysis between square wave and differential pulse is shown in Fig. 2. The square wave was found to have greater sensitivity than the differential pulse and was selected for all experiments.

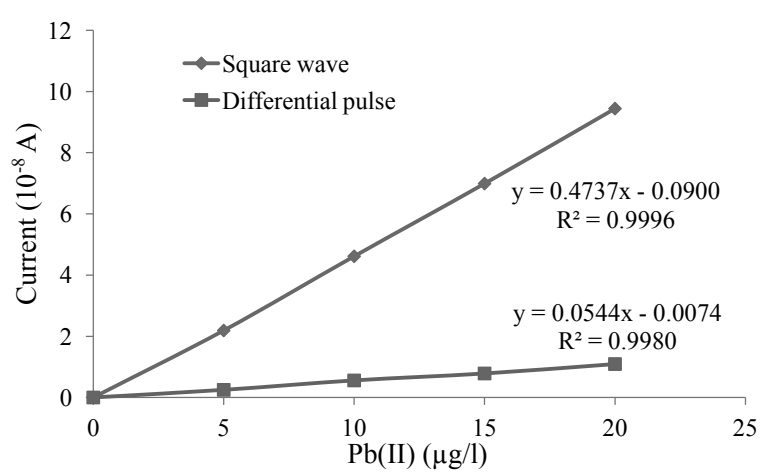

Fig. 2 The comparison of peak current between square wave and differential pulse of $\mathrm{Pb}$ (II) in $0.01 \mathrm{M}$ ammonium acetate containing $10 \mu \mathrm{M}$ 8-hydroxyquinoline at $\mathrm{pH} 8.0$.

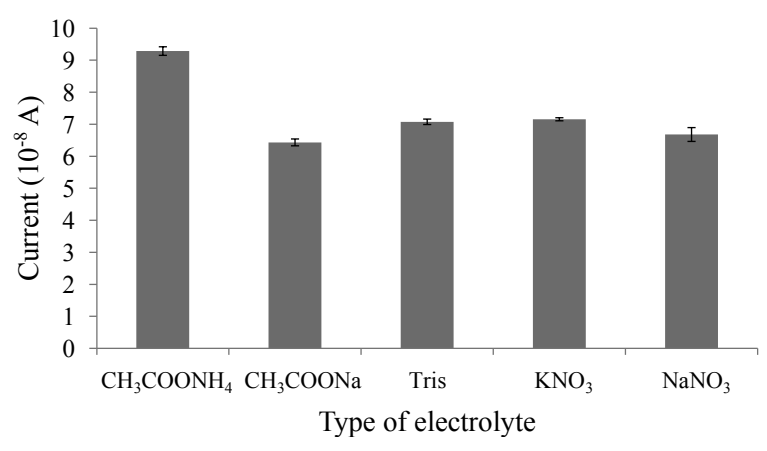

Fig. 3 Effect of supporting electrolyte on the peak current of $20 \mu \mathrm{g} / \mathrm{l} \mathrm{Pb}$ (II) in the presence of $10 \mu \mathrm{M}$ 8-hydroxyquinoline at $\mathrm{pH} 8.0$.

\section{Effect of the supporting electrolyte}

Electrochemical measurements are commonly carried out in a variety of supporting electrolytes to decrease the resistance of the solution, to reduce the effect of migration, and to maintain a constant ionic strength ${ }^{12}$. The effects of different supporting electrolytes including $0.01 \mathrm{M}$ of $\mathrm{CH}_{3} \mathrm{COONH}_{4}, \mathrm{CH}_{3} \mathrm{COONa}$, Tris, $\mathrm{KNO}_{3}$, and $\mathrm{NaNO}_{3}$ are shown in Fig. 3. The highest peak height was achieved in $\mathrm{CH}_{3} \mathrm{COONH}_{4}$ solution. Thus $\mathrm{CH}_{3} \mathrm{COONH}_{4}$ was used as a supporting electrolyte for further experiments.

\section{Effect of supporting electrolyte concentration}

The effect of concentration of the supporting electrolyte on the stripping peak current of $\mathrm{Pb}$ (II) was studied by varying the concentration of ammonium acetate within the range of $0.01-0.5 \mathrm{M}$ (Fig. 4). The maximum peak current was observed in $0.1 \mathrm{M}$ ammonium acetate. The increasing of the concentration of ammonium acetate was found to decrease the peak current due to the formation of a weak complex between acetate with $\mathrm{Pb}(\mathrm{II})^{24}$. Consequently, an 


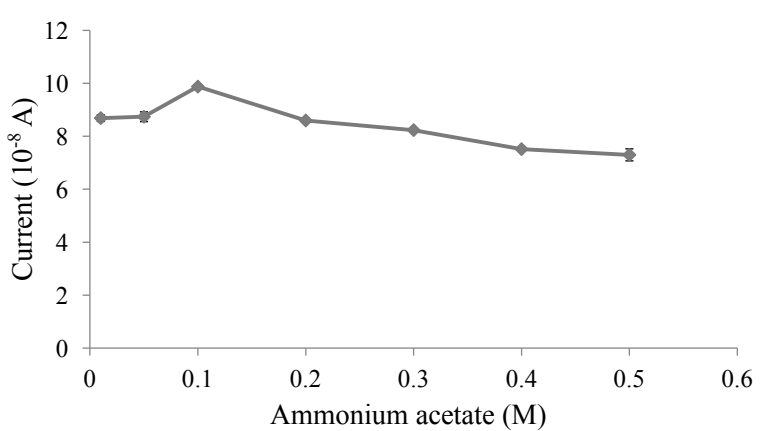

Fig. 4 Effect of ammonium acetate concentration on the peak current of $20 \mu \mathrm{g} / \mathrm{Pb}$ (II) in the presence of $10 \mu \mathrm{g} / 1$ 8-hydroxyquinoline at $\mathrm{pH}$ 8.0.

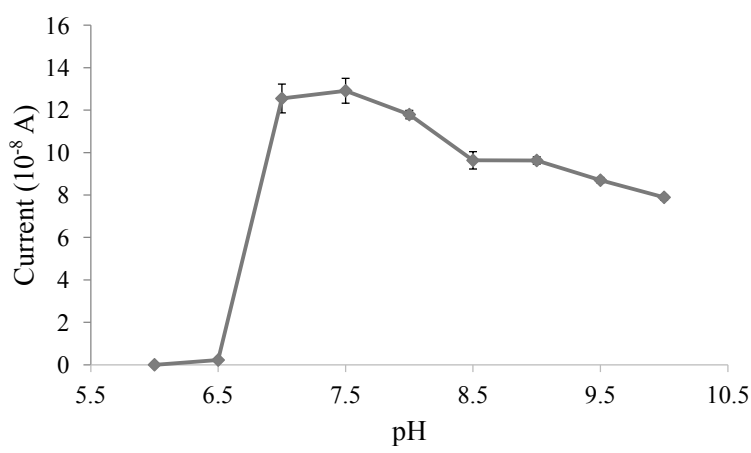

Fig. 5 Effect of $\mathrm{pH}$ on the peak current of $20 \mu \mathrm{g} / \mathrm{l} \mathrm{Pb}$ (II) in $0.1 \mathrm{M}$ ammonium acetate containing $10 \mu \mathrm{M}$ 8-hydroxyquinoline.

optimum ammonium acetate concentration of $0.1 \mathrm{M}$ was selected for the next experiments.

\section{Effect of pH}

The influence of $\mathrm{pH}$ on the stripping peak current of $\mathrm{Pb}$ (II) was studied in the $\mathrm{pH}$ range of $6.0-10.0$ with the results shown in Fig. 5. It indicates that in the $\mathrm{pH}$ range of 6.0-7.5, the peak current of the lead complex increases with the increasing of $\mathrm{pH}$ to reach the maximum at $\mathrm{pH} 7.5$ and then decreases from $\mathrm{pH} 8.0-10.0$. Thus $\mathrm{pH} 7.5$ was chosen for further studies. At very low $\mathrm{pH}$, the protonation of $-\mathrm{NH}$ groups in 8-hydroxyquinoline occurs whereas at high $\mathrm{pH}$ the hydrolysis of $\mathrm{Pb}$ (II) increasingly affects the formation of $\mathrm{Pb}(\mathrm{II})$ and 8-hydroxyquinoline complexes ${ }^{25}$; therefore, at lower or higher $\mathrm{pH}$ the complexation of 8-hydroxyquinoline with $\mathrm{Pb}$ (II) ions decreases.

\section{Effect of 8-hydroxyquinoline concentration}

The effect of the 8-hydroxyquinoline concentration on the cathodic stripping peak current of $20 \mu \mathrm{g} / \mathrm{l}$ $\mathrm{Pb}(\mathrm{II})$ in $0.1 \mathrm{M}$ ammonium acetate at $\mathrm{pH} 7.5$ with an

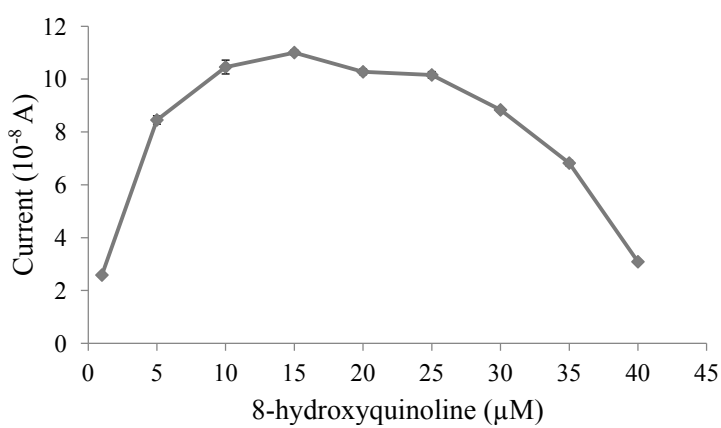

Fig. 6 Effect of 8-hydroxyquinoline concentration on the peak current of $20 \mu \mathrm{g} / \mathrm{l} \mathrm{Pb}$ (II) in $0.1 \mathrm{M}$ ammonium acetate at $\mathrm{pH} 7.5$.

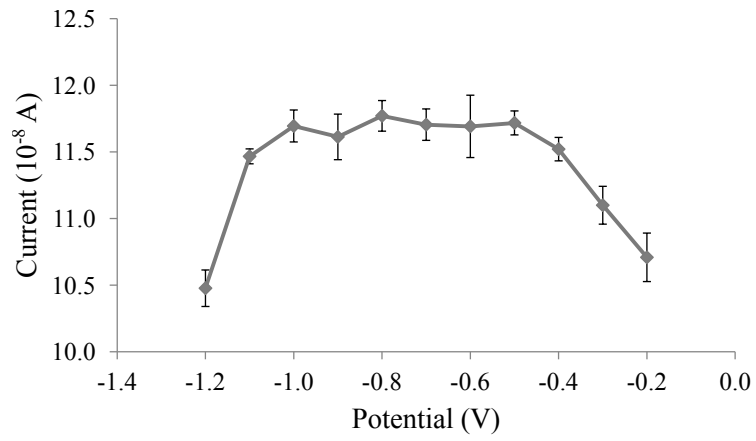

Fig. 7 Effect of accumulation potential on the peak current of $20 \mu \mathrm{g} / \mathrm{l} \mathrm{Pb}$ (II) in $0.1 \mathrm{M}$ ammonium acetate at $\mathrm{pH}$ 7.5.

accumulation potential of $-1.1 \mathrm{~V}$ for $60 \mathrm{~s}$ is shown in Fig. 6. The stripping peak current for $\mathrm{Pb}$ (II) increased up to $15 \mu \mathrm{M}$ and then decreased due to the competition of 8-hydroxyquinoline with $\mathrm{Pb}(\mathrm{II})-8$-hydroxyquinoline complexes in adsorption onto the mercury drop electrode $^{14}$. Hence the 8-hydroxyquinoline concentration of $15 \mu \mathrm{M}$ was selected as an optimum value for further experiments.

\section{Effect of accumulation potential}

The effect of varying accumulation potential on the peak current for $\mathrm{Pb}$ (II) determination is shown in Fig. 7. The accumulation potential was varied between -1.2 and $-0.2 \mathrm{~V}$. The obtained results revealed that the peak current of $\mathrm{Pb}$ (II) was constant between $-0.8 \mathrm{~V}$ to $-0.5 \mathrm{~V}$. Thus an accumulation potential of $-0.7 \mathrm{~V}$ was selected for lead accumulation because the peak at $-0.7 \mathrm{~V}$ exhibits constant current trend and provides better sensitivity.

\section{Effect of accumulation time}

The effect of varying accumulation time on the peak current for $\mathrm{Pb}$ (II) determination is shown in Fig. 8. It 


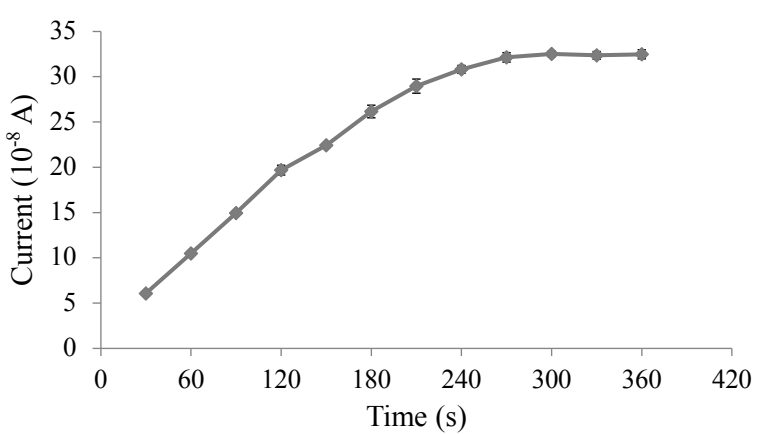

Fig. 8 Effect of accumulation potential on the peak current of $20 \mu \mathrm{g} / \mathrm{l} \mathrm{Pb}$ (II) in $0.1 \mathrm{M}$ ammonium acetate containing $15 \mu \mathrm{M}$ 8-hydroxyquinoline at $\mathrm{pH}$ 7.5.

was found that the peak current of $\mathrm{Pb}(\mathrm{II})$ increased linearly with the accumulation time, gradually levelling off at periods longer than $270 \mathrm{~s}$ which is presumably due to the saturation of the HMDE surface at longer accumulation time ${ }^{26}$. Thus an adsorption time of $120 \mathrm{~s}$ was used throughout this work as it combines good sensitivity with relatively short analysis time.

\section{Effect of scan rate and pulse amplitude}

To improve the sensitivity for the determination of $\mathrm{Pb}(\mathrm{II})$, the influences of parameters of square wave voltammetry on the measurement of lead were investigated. The effect of scan rate and pulse amplitude on the peak current in the range of $0.1-0.9 \mathrm{~V} / \mathrm{s}$ and $10-50 \mathrm{mV}$ is shown in Fig. 9a,b. The peak current for lead increased with increasing scan rate and pulse amplitude; therefore, a scan rate of $0.3 \mathrm{~V} / \mathrm{s}$ and pulse amplitude $20 \mathrm{mV}$ were selected as the criteria for better sensitivity and peak shape.

\section{Analytical performance}

At the optimized conditions, the linear calibration graph was obtained in the concentration range of $0.5-90.0 \mu \mathrm{g} / \mathrm{l}$ with the correlation coefficient of 0.9973. The limit of detection (LOD) and the limit of quantification (LOQ) were calculated by carrying out the above procedure with 10 blank samples and calculating $(3 \times \mathrm{SD}) / m$ for LOD and $(10 \times \mathrm{SD}) / m$ for LOQ, where SD is the standard deviation of blank and $m$ is the slope of calibration graph, which were found to be $0.108 \mu \mathrm{g} / \mathrm{l}$ and $0.360 \mu \mathrm{g} / \mathrm{l}$, respectively. The accuracy of the determination was tested by spiking the canned fish samples before sample digestion with various concentrations of $\mathrm{Pb}(\mathrm{II})$. The percent recovery values were found to be in the range of 93.7-95.1\% (Table 1). The analytical precision of the method was estimated from the reproducibility
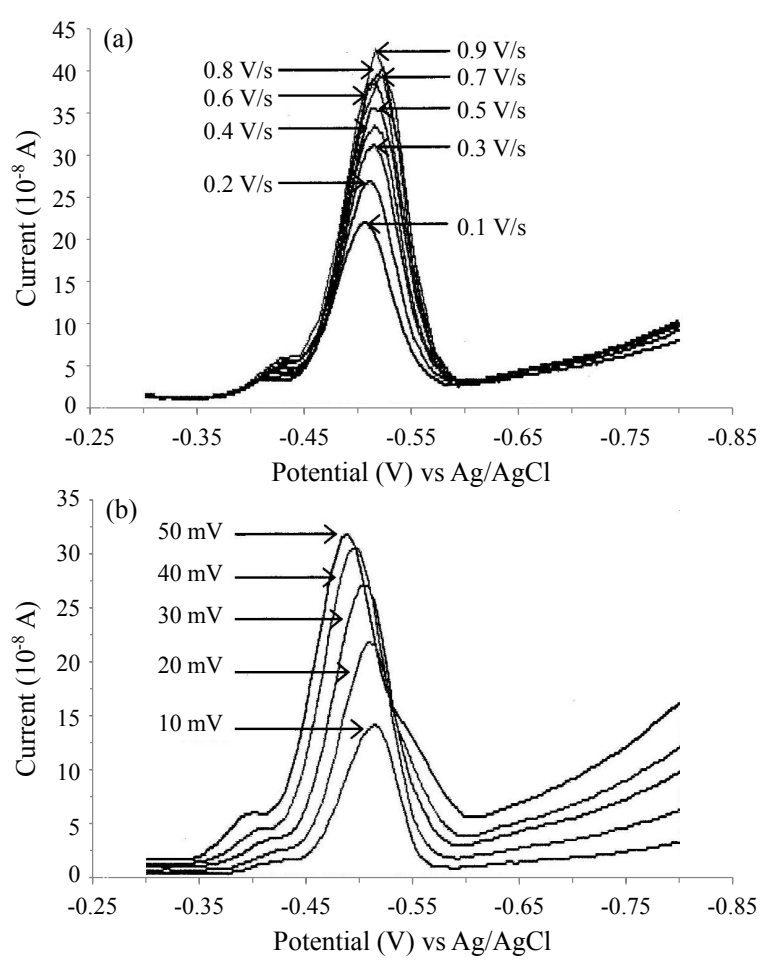

Fig. 9 Square wave voltammogram of varied scan rates (a) and pulse amplitudes (b) on the peak current of $20 \mu \mathrm{g} / 1$ $\mathrm{Pb}$ (II) in $0.1 \mathrm{M}$ ammonium acetate containing $15 \mu \mathrm{M}$ 8-hydroxyquinoline at $\mathrm{pH}$ 7.5.

Table 1 The percent recovery of $\mathrm{Pb}$ (II) at spiked concentration of 10,20 , and $30 \mu \mathrm{g} / \mathrm{l}$ in canned fish.

\begin{tabular}{lcc}
\hline Sample Type & $\mathrm{Pb}(\mathrm{II})$ concentration $(\mu \mathrm{g} / \mathrm{l})$ & \%Recovery \\
\hline sample & 9.6 & - \\
$+10 \mu \mathrm{g} / \mathrm{l} \mathrm{Pb}(\mathrm{II})$ & 19.0 & 94.0 \\
$+20 \mu \mathrm{g} / \mathrm{Pb}(\mathrm{II})$ & 28.3 & 93.7 \\
$+30 \mu \mathrm{g} / \mathrm{l} \mathrm{Pb}(\mathrm{II})$ & 38.1 & 95.1 \\
\hline
\end{tabular}

of 10 determinations at three lead concentrations. The relative standard deviations at lead concentrations of $1.0,5.0$, and $10.0 \mu \mathrm{g} / \mathrm{l}$ were $6 \%, 2 \%$, and $2 \%$, respectively.

\section{Interferences}

Possible interference by other metals with the adsorptive cathodic stripping voltammetry determination of $\mathrm{Pb}$ (II) was investigated by the addition of the interfering ion to a solution containing $20.0 \mu \mathrm{g} / \mathrm{l}$ of $\mathrm{Pb}(\mathrm{II})$ and were carried out the measurements under optimized conditions with the results summarized in Table 2. Several ions including $\mathrm{Fe}^{2+}, \mathrm{Cr}^{3+}, \mathrm{Mn}^{2+}$, and $\mathrm{Hg}^{2+}$ (5-fold concentration); $\mathrm{Sn}^{2+}$ (3-fold concentration); $\mathrm{Cd}^{2+}, \mathrm{Zn}^{2+}$, and $\mathrm{Al}^{3+}$ (equal concentration); have 
Table 2 Change in peak current of $20 \mu \mathrm{g} / \mathrm{l} \mathrm{Pb}$ (II) in the presence of other ions.

\begin{tabular}{lcc}
\hline Metal & Concentration $(\mu \mathrm{g} / \mathrm{l})$ & Change in peak current $(\%)$ \\
\hline $\mathrm{Pb}^{2+}$ & 100 & -0.3 \\
$\mathrm{Mn}^{2+}$ & 100 & 7.7 \\
$\mathrm{Cr}^{3+}$ & 100 & 4.3 \\
$\mathrm{Hg}^{2+}$ & 100 & -1.4 \\
$\mathrm{Sn}^{2+}$ & 60 & -10.8 \\
$\mathrm{Cd}^{2+}$ & 20 & -13.7 \\
$\mathrm{Zn}^{2+}$ & 20 & -8.2 \\
$\mathrm{Al}^{3+}$ & 20 & -12.9 \\
$\mathrm{Cu}^{2+}$ & 20 & -32.9 \\
$\mathrm{Ni}^{2+}$ & 20 & -29.5 \\
\hline
\end{tabular}

Table $3 \mathrm{~Pb}$ (II) concentration in canned fish samples by standard addition method.

\begin{tabular}{lc}
\hline Sample number & Pb concentration $(\mu \mathrm{g} / \mathrm{g})$ \\
\hline 1 & 0.160 \\
2 & 0.285 \\
3 & 0.208 \\
4 & 0.180 \\
5 & 0.259 \\
6 & 0.151 \\
7 & 0.140 \\
8 & 0.265 \\
9 & 0.121 \\
10 & 0.277 \\
\hline
\end{tabular}

only negligible effect on the determination of $\mathrm{Pb}^{2+}$. Although equal concentrations of $\mathrm{Cu}^{2+}$ and $\mathrm{Ni}^{2+}$ interfere significantly by decreasing the $\mathrm{Pb}^{2+}$ signal, the peak of $\mathrm{Pb}^{2+}$ is still well separated.

\section{Applications}

The proposed method was applied to the determination of $\mathrm{Pb}(\mathrm{II})$ in canned fish samples. The standard addition method was used to eliminate the matrix effect. As shown in Table 3, the concentration of $\mathrm{Pb}$ (II) in canned fish samples (wet weight) was found in the range of $0.121-0.285 \mu \mathrm{g} / \mathrm{g}$, which were lower than standard limited for food contamination $(<1.0 \mu \mathrm{g} / \mathrm{g})$ issued by the Ministry of Public Health of Thailand.

\section{Conclusion}

The present study demonstrates that square wave adsorptive cathodic stripping voltammetry of lead based on accumulation of $\mathrm{Pb}$ (II)-8-hydroxyquinoline complex can be used to determine trace amounts of lead in canned fish samples. This method is simple, sensitive, inexpensive and rapid with the optimum condition of $0.1 \mathrm{M}$ ammonium acetate at $\mathrm{pH} 7.5$ as supporting electrolyte, $15 \mu \mathrm{M}$ 8-hydroxyquinoline, accumulation potential $-0.70 \mathrm{~V}$, adsorption time $120 \mathrm{~s}$, scan rate $0.3 \mathrm{~V} / \mathrm{s}$, and pulse amplitude of $20 \mathrm{mV}$. Most metal ions have negligible interference effect except $\mathrm{Cu}^{2+}$ and $\mathrm{Ni}^{2+}$. LOD and LOQ are $0.108 \mu \mathrm{g} / \mathrm{l}$ and $0.360 \mu \mathrm{g} / \mathrm{l}$, respectively, with satisfactory recovery of $93.7-95.1 \%$ and reproducibility of $2 \%$ for $5.0 \mu \mathrm{g} / \mathrm{l}$ $\mathrm{Pb}(\mathrm{II})$.

Acknowledgements: This work was financially supported by the Centre for Innovation in Chemistry: Postgraduate Education and Research Programme in Chemistry (PERCH-CIC) as well as the Graduate School and Department of Chemistry, Faculty of Science, of Prince of Songkla University.

\section{REFERENCES}

1. Khansari FE, Ghazi-Khansari M, Abdollahi M (2005) Heavy metals content of canned tuna fish. Food Chem 93, 293-6.

2. Groth E III (1986) Lead in canned foods. Agr Hum Val 3, 91-145.

3. Ikem A, Egiebor NO (2005) Assessment of trace elements in canned fishes (mackerel, tuna, salmon, sardines and herrings) marketed in Georgia and Alabama (United States of America). J Food Compos Anal 18, 771-87.

4. Voegborlo RB, El-Methnani AM, Abedin MZ (1999) Mercury, cadmium and lead content of canned tuna fish. Food Chem 67, 341-5.

5. Ashraf W, Seddigi Z, Abulkibash A, Khalid M (2006) Levels of selected metals in canned fish consumed in Kingdom of Saudi Arabia. Environ Monit Assess 117, 271-9.

6. Santos D, Barbosa F, Tomazelli A, Krug F, Nóbrega $\mathrm{J}$, Arruda M (2002) Determination of $\mathrm{Cd}$ and $\mathrm{Pb}$ in food slurries by GFAAS using cryogenic grinding for sample preparation. Anal Bioanal Chem 373, 183-9.

7. Chew LT, Bradley DA, Amin YM, Maah MJ (2000) Zinc, lead and copper in human teeth measured by induced coupled argon plasma atomic emission spectroscopy (ICP-AES). Appl Radiat Isot 53, 633-8.

8. Chen S, Zhang Z, Yu H, Liu W, Sun M (2002) Determination of trace lead by hydride generation-inductively coupled plasma-mass spectrometry. Anal Chim Acta 463, 177-88.

9. Fajgelj A, Byrne AR (1995) Determination of lead, cadmium and thallium by neutron activation analysis in environmental samples. J Radioanal Nucl Chem 189, 333-43.

10. Golob T, Doberšek U, Kump P, Nečemer M (2005) Determination of trace and minor elements in Slovenian honey by total reflection X-ray fluorescence spectroscopy. Food Chem 91, 593-600.

11. Hu C, Wu K, Dai X, Hu S (2003) Simultaneous determination of lead(II) and cadmium(II) at a diacetyldi- 
oxime modified carbon paste electrode by differential pulse stripping voltammetry. Talanta 60, 17-24.

12. Wang J (2000) Analytical Electrochemistry, 2nd edn. Wiley-VCH, New York, pp 75-84.

13. Abollino O, Aceto M, Sarzanini C, Mentasti E (1999) Behavior of different metal/ligand systems in adsorptive cathodic stripping voltammetry. Electroanalysis 11, 870-8.

14. Shemirani F, Rajabi M, Asghari A, Milani-Hosseini MR (2005) Simultaneous determination of traces of cadmium and zinc by adsorptive stripping voltammetry. Can J Anal Sci Spectros 50, 175-81.

15. Buffle J, Tercier-Waeber M-L (2005) Voltammetric environmental trace-metal analysis and speciation: from laboratory to in situ measurements. Trends Anal Chem 24, 172-91.

16. Abu-Zuhri AZ, Voelter W (1998) Applications of adsorptive stripping voltammetry for the trace analysis of metals, pharmaceuticals and biomolecules. Fresen $J$ Anal Chem 360, 1-9.

17. van den Berg CMG (1986) Determination of copper, cadmium and lead in seawater by cathodic stripping voltammetry of complexes with 8-hydroxyquinoline. J Electroanal Chem Interfacial Electrochem 215, $111-21$.

18. Wu QG, Batley GE (1995) Determination of sub-nanomolar concentrations of lead in sea water by adsorptive stripping voltammetry with xylenol orange. Anal Chim Acta 309, 95-101.

19. Yokoi K, Yamaguchi A, Mizumachi M, Koide T (1995) Direct determination of trace concentrations of lead in fresh water samples by adsorptive cathodic stripping voltammetry of a lead-Calcein Blue complex. Anal Chim Acta 316, 363-9.

20. Shams E, Babaei A, Soltaninezhad M (2004) Simultaneous determination of copper, zinc and lead by adsorptive stripping voltammetry in the presence of Morin. Anal Chim Acta 501, 119-24.

21. Babaei A, Shams E, Samadzadeh A (2006) Simultaneous determination of copper, bismuth and lead by adsorptive stripping voltammetry in the presence of thymolphthalexone. Anal Sci 22, 955-9.

22. Garay F, Solís V (1999) Square wave stripping voltammetry of Cd-oxine complexes; surface redox reactions. $J$ Electroanal Chem 476, 165-70.

23. Arancibia V, Alarcón L, Segura R (2004) Supercritical fluid extraction of cadmium as Cd-oxine complex from human hair: Determination by square wave anodic or adsorptive stripping voltammetry. Anal Chim Acta 502, 189-94.

24. Degefa TH, Chandravanshi BS, Alemu H (1999) Differential pulse anodic strippping voltammetric determination of lead(II) with $N$-p-chlorophenylcinnamohydroxamic acid modified carbon paste electrode. Electroanalysis 11, 1305-11.

25. Jurado-González JA, Galindo-Riaño MD, García-Vargas M (2003) Experimental designs in the development of a new method for the sensitive determination of cadmium in seawater by adsorptive cathodic stripping voltammetry. Anal Chim Acta 487, 229-41.

26. Amini MK, Kabiri M (2005) Determination of trace amounts of nickel by differential pulse adsorptive cathodic stripping voltammetry using calconcarboxylic acid as a chelating agent. J Iran Chem Soc 2, 32-9. 